\title{
小特集 「インフラ構造物のモニタリング」
}

目次

1. 小特集にあたって . 布施孝志 (東京大学)

264

2 . 衛星リモートセンシングによるフィルダムの外部変形計測

..本田謙一・浅田典親・虫明成生（国際航業） 266

3.UAV を用いた護岸の健全度評価

・木本啓介（計測リサーチコンサルタント）・坂本和雄（太田川河川事務所）・

田村友紀夫・太田 智（パシフィックコンサルタンツ） 270

4. 地下埋設管等の点群計測システムの開発・ .大月庄治（アスコ） 275

\section{1.小特集にあたって}

布施 孝志*

高度経済成長期以降, 多数のインフラ構造物が建設 され，わが国の経済活動を支えてきた。例えば，1964 年の東京オリンピック開催に向けて, 東海道新幹線や 首都高速道路などが整備されたが, 当時のインフラ構 造物は既に50歳を迎之, その維持管理が契緊の課題と なっている。また，2012年の笹子トンネル天井板落下 事故は, インフラ構造物のメンテナンスの重要性を世 に知らしめたものとして, 記憶に新しいところである。

本小特集では, 夕゙ム, 河川構造物, 下水道管, 道路 施設, 鉄道施設など, 我及の生活を支えるインフラ構 造物のメンテナンスに向け，それらのモニタリング技 術を集め, その技術進展と有効性について, 今号から 3 号にわたって論ずる。インフラ構造物のモニタリン
グ技術は, 多様なセンサを用いて行われている。光ファ イバーやICタグなどの埋め込み型センサの利用も進 んでいるが, 本小特集では, 学会員に有用と思われる 遠隔型のモニタリング技術に焦点を絞る。

なお，MMSによる道路の路面性状調査は，小特集 「モバイルマッピングによる道路空間の計測」(写真測 量とリモートセンシング, Vol.47, No.5, 2008.)に おいて，また，UAVによるインフラ点検は，小特集 「UAV を用いた調查・計測事例と安全確保に向けた取 り組み」(写真測量とリモートセンシング, Vol. 54, No. 2，2015.)に打いても报っている。そちらもあわせて 参照されたい。 


\section{小特集「インフラ構造物のモニタリング」ロ絵}

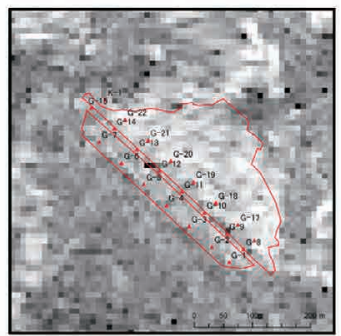

(a) 強度画像

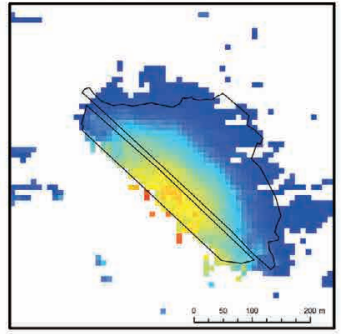

(c) $2008 / 1 / 15$

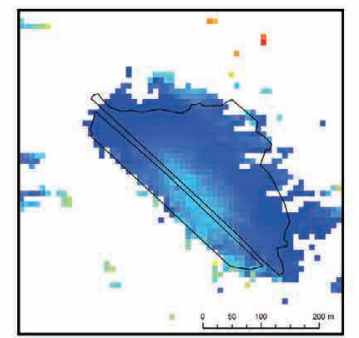

(b) $2007 / 4 / 14$

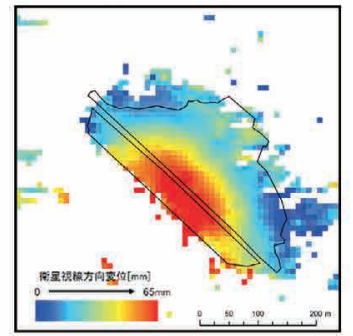

(d) $2010 / 1 / 20$

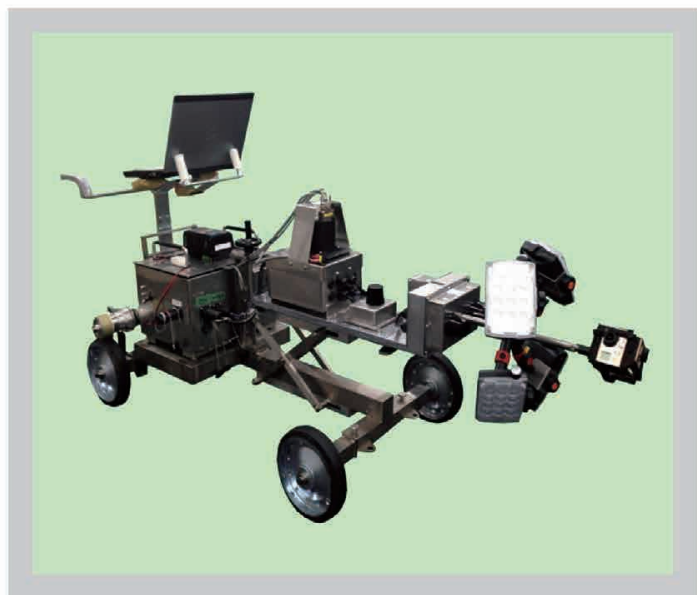

小特集 4 地下埋設管等の計測用ロボット

小特集 2 南行軌道の干渉 SAR によるダムの

衛星視線方向変位

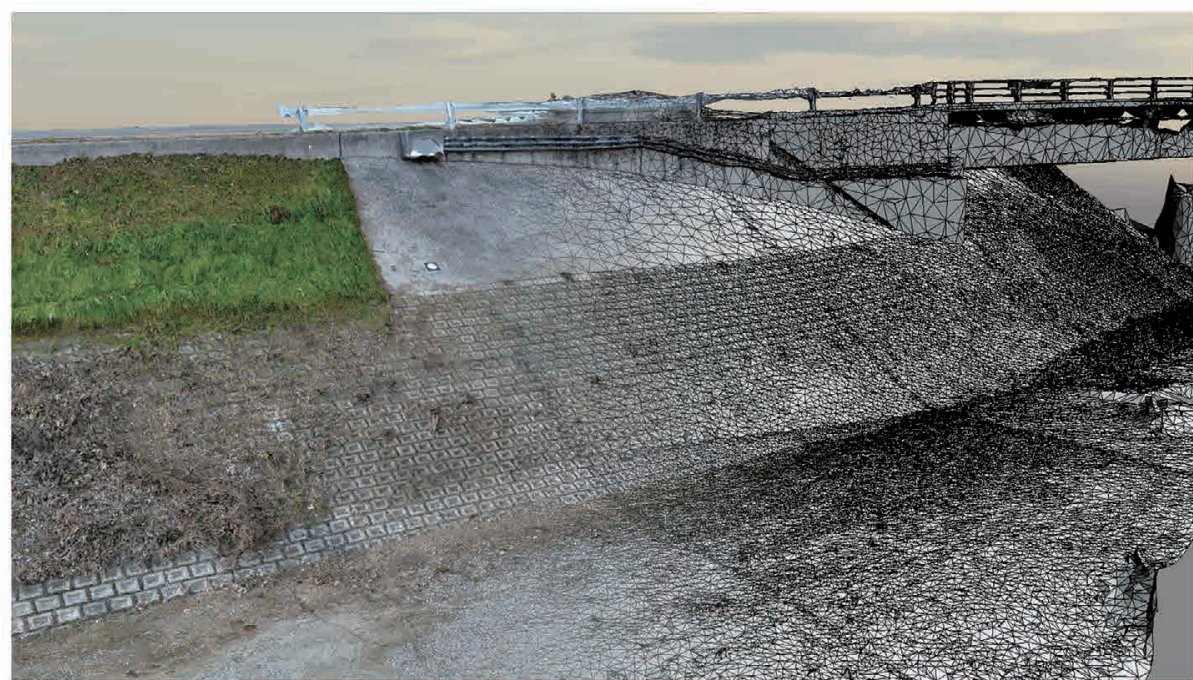

小特集 3 SfM により作成した河川護岸の 3 D モデル 